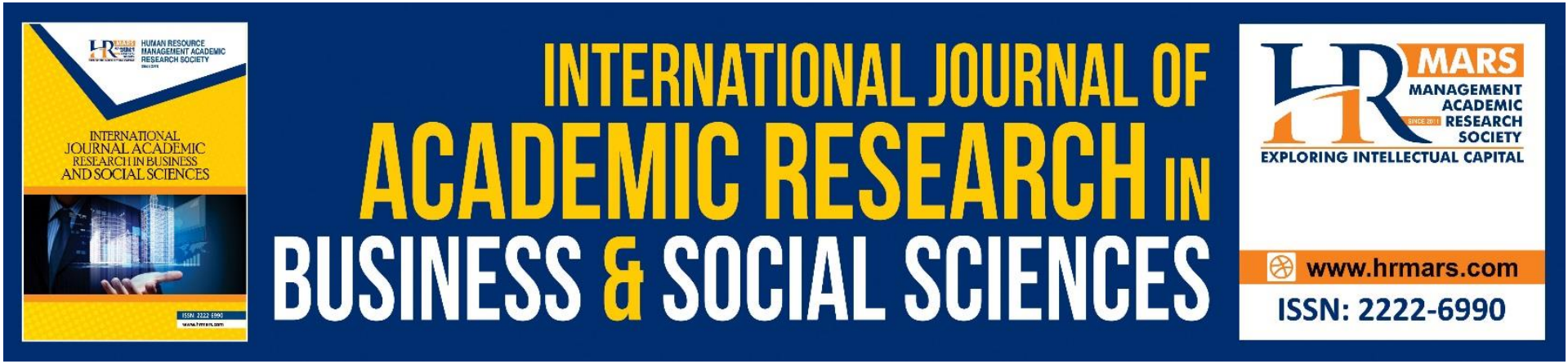

\title{
Exploring Effect of Leadership Styles on Task Performance: A Conceptual Framework
}

\section{Chua Han Cheng, Zahir Bin Osman}

To Link this Article: http://dx.doi.org/10.6007/IJARBSS/v11-i12/10977

DOI:10.6007/IJARBSS/v11-i12/10977

Received: 13 October 2021, Revised: 18 November 2021, Accepted: 30 November 2021

Published Online: 23 December 2021

In-Text Citation: (Cheng \& Osman, 2021)

To Cite this Article: Cheng, C. H., \& Osman, Z. Bin. (2021). Exploring Effect of Leadership Styles on Task Performance: A Conceptual Framework. International Journal of Academic Research in Business and Social Sciences, 11(12), 1595-1615.

\section{Copyright: (c) 2021 The Author(s)}

Published by Human Resource Management Academic Research Society (www.hrmars.com)

This article is published under the Creative Commons Attribution (CC BY 4.0) license. Anyone may reproduce, distribute, translate and create derivative works of this article (for both commercial and non0-commercial purposes), subject to full attribution to the original publication and authors. The full terms of this license may be seen at: http://creativecommons.org/licences/by/4.0/legalcode

Vol. 11, No. 12, 2021, Pg. $1595-1615$

Full Terms \& Conditions of access and use can be found at http://hrmars.com/index.php/pages/detail/publication-ethics 


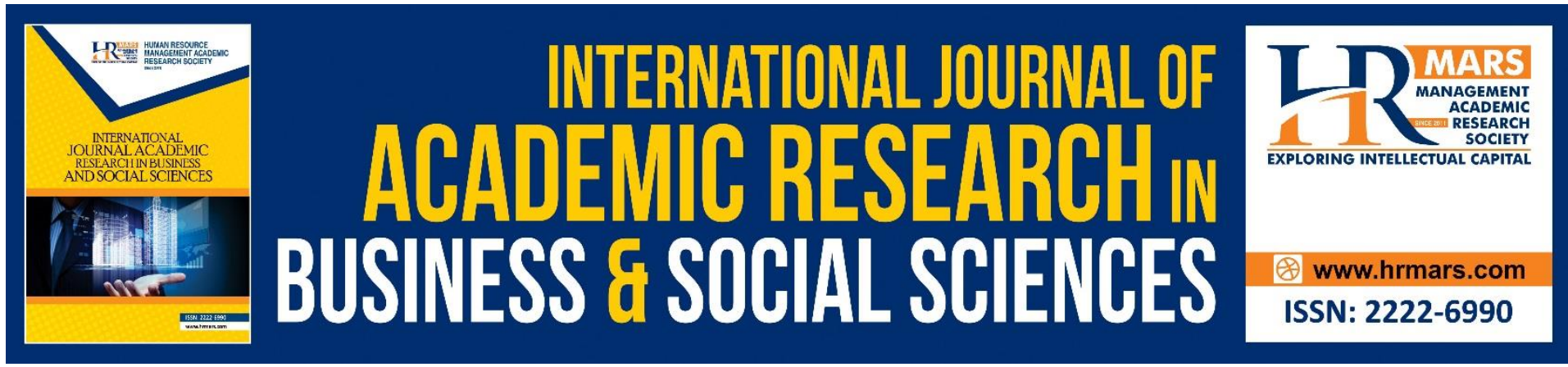

\title{
Exploring Effect of Leadership Styles on Task Performance: A Conceptual Framework
}

\author{
Chua Han Cheng, Zahir Bin Osman \\ Cluster of Business and Management, Open University Malaysia (OUM), Malaysia \\ Email: chuahancheng@yahoo.com,zahir_osman@oum.edu.my
}

\begin{abstract}
It is widely accepted by researchers that leaders play important roles in improving employee performance. However, consensus on adopting leadership styles is subjected to argumentative rigour. Previous studies have found evidence that directive leadership style is effective in resolving team's task and role ambiguity; in improving performance and core task performance. Among other leadership behaviours, supportive leadership is identified as an effective leadership approach that heeds employees' personal needs; providing them with social and emotional support. Directive and supportive leadership styles are found to complement each other resulting in improved performance outcomes. Path-Goal Theory proposes both leadership behaviours are among the rooted four leadership styles, namely: directive, supportive, participative, and achievement-oriented, that optimizes the employee and work environment to achieve a goal. Several factors including motivation and organisational citizenship behaviour are perceived to determine the appropriateness of leadership styles to be employed situationally. This paper presents a conceptual framework that depicts the mediating effect of these two factors on the relationship between leadership styles and task performance. Empirical results will be presented in the sequel to this theoretical study.
\end{abstract}

Keywords: Directive Leadership, Supportive Leadership, Task Performance, Motivation, Organisational Citizenship Behaviour

\section{Introduction}

Research suggested that leaders adopting various types of leadership styles influence task performance (Lorinkova et al., 2013; Martin et al., 2013). Leadership can be viewed as a process that influences others, including motivating subordinates and creating favourable workplace conditions, influencing followers to achieve the organisational goal or desired outcomes (Kramer et al., 2018; Yukl, 2013). Path-Goal Theory of Leadership (House, 1971) centralises on four categories of leadership behaviours, namely directive, supportive, participative, and achievement-oriented leadership.

Although it is widely accepted that the directive leadership approach is effective in resolving followers' tasks and role ambiguity resulting in positive organisational outcomes, dissatisfaction among individuals could arise due to the coercive nature of the directive leadership approach. Path-Goal Theory of Leadership (House, 1971) identifies a supportive 
leadership style as an effective leadership approach that takes into consideration employees' personal needs and provides them with social-psychological supports, for which directive leadership is inadequate (Shin et al., 2016). Management and psychology literature suggested that individuals need motivation, reward, satisfaction for better performance, and willingness to perform extra-role activities discretionally (Ibrahim \& Aslinda, 2014; Bateman \& Snell, 2011). These extra-role activities would enhance positive organisational citizenship behaviour (OCB) on the main effects of employee dispositions and job attitudes, which are essential for the enhancement of the organisation's productivity outcome (Itiola et al., 2014). This theoretical study explores the influence of motivation and OCB on the relationship between leadership styles, namely directive and supportive leadership style, and task performance.

\section{Problem Statement}

Amongst the distinct leadership typologies, the directive leadership style has received much less attention in organisational behaviour literature with proliferated studies on transformational and transactional leadership behaviours (Nielsen et al., 2019; Sun \& Henderson, 2017). There are calls from researchers for the requisite to broaden the breadth of leadership development based on the belief that 'not a single type of leadership could fit in all situations (Wright, 2017; Yukl, 2013).

It was reported in Malaysia's newspaper media (Veena, 2020) that the Department of Occupational Safety and Health's (DOSH's) statistics have indicated 169 deaths and 3,911 accidents in the Malaysian construction and related industries which have recorded the highest number of deaths across the nation's economic sectors for the Year 2018. Unfortunately, the rate of fatality of industrial accidents has increased annually since the Year 2018. Several cases related to tragic incidents and issues caused by quarrying activities were reported by local newspaper media ("Flying Rocks from Quarry Blasting", 2007; Idris, 2008; Shah, 2013; "Bodies of Two Foreign Workers Buried", 2014). Many of these incidents were fatal and related to: blasting operations; the collapse of the rock face and landslide that trapped heavy machinery operators; fly rocks that caused injuries to civilians; and damage to private properties and amenities. The causes for these incidents tend to point towards negligence and the indifferent attitude of workers at operation levels in the quarry organisations (Rahman et al., 2015). The problem is worrisome to the industry's players as disruption in production due to work suspension would have detrimental consequences financially. The problem has become a managerial issue and is urgently required to establish an effective management structure to manage workers at the operation level to overcome these challenges. It is recommended to examine employee task performance behaviour related to the effectiveness of leadership approaches used, supervisory, social, psychological and work environment perspectives.

Little study has been found on the influence of directive and supportive leadership on individual task performance. For example, studies: (i) on the impact of transformational and autocratic leadership styles and personality on organisational commitment in Malaysia (Kumar \& Chung, 2019); (ii) on the influence of leadership styles on employee performance related to the jewellery industry (Lor \& Hassan, 2017); (iii) on the impact of leadership styles (democratic, lasses-faire and autocratic) on employee performance of a private organisation in Selangor of Malaysia (Basit et al., 2017); (iv) on the influence of directive and supportive leadership styles on employee job satisfaction in the banking industry in Kenya with environmental contingency factors as moderators (Mwaisaka et al., 2019); and (v) on the single relationship between employee motivation and work performance for mining 
companies in Ghana (Kuranchie-Mensah, \& Amponsah-Tawiah, 2015). Thus, to answer the call to fill this contextual gap, this study aims to investigate the influence of directive and supportive leadership on task performance, which would also include the influence of the hypothesised key factors on the relationships. The investigation is to answer the call for future research by researchers (Martin et al., 2013) for examining the impact of different types of leadership styles on task performance.

In social science research literature and leadership studies, notably in Malaysia, there is a lack of research study in examining interrelated relationships of dependent and independent variables that include: directive leadership, supportive leadership, OCB, motivation and task performance. This study attempts to fill this gap and aims to broaden the knowledge in leadership development as well as to add to the body of knowledge in multivariate statistical techniques by employing Structural Equation Modeling (SEM).

\section{Objectives of the Study}

This study aims to add to the body of knowledge of leadership development on the impacts of differential leadership styles (directive and supportive) on employee task performance and the mediating roles of motivation and OCB on the relationships. Theoretically, this study hopes to develop a new hypothesised model as a theory fitting model. The validity of this hypothesised model will be analysed by using Structural Equation Modeling (SEM) in subsequent empirical studies. Hopefully, the findings from subsequent empirical studies will be able to contribute to stakeholders such as managerial practitioners to assist them in understanding the importance of selecting appropriate leadership styles for managing their workforce. The objectives of this study:

1. To determine whether directive leadership has a positive and significant influence on employee task performance behaviour

2. To determine whether supportive leadership has a positive and significant influence on employee task performance behaviour.

3. To determine whether motivation has a positive and significant mediating effect on the relationship between directive leadership approach and employee task performance behaviour

4. To determine whether OCB has a positive and significant mediating effect on the relationship between directive leadership approach and employee task performance behaviour

5. To determine whether motivation has a positive and significant mediating effect on the relationship between supportive leadership approach and employee task performance behaviour

6. To determine whether OCB has a positive and significant mediating effect on the relationship between supportive leadership approach and employee task performance behaviour

\section{The Key Concepts of this Study Directive leadership}

This study defines directive leadership as leadership behaviour that provides followers specific instruction and guidelines to avoid task and role ambiguity for attaining required performance standards (Lorinkova et al., 2013). A directive leader will possess legitimate power to induce financial compensation to followers, conditional upon their performance. This leadership behaviour often involves power distance relationship between a leader and 
his/her followers that explain influencing process of leadership on followers (Mintzberg, 1983 ) in attaining desirable organisational outcome. Seven dimensions have been identified as related to the influencing process using power relation include legitimate, reward, coercive, expert, referent (French \& Raven, 1959), agent persuasiveness, and control over information (Yukl \& Fable, 1991). Directive top-down leadership was found to be present in the study on group cohesiveness in a certain organisational context (Aris \& Kamarudin, 2009). Group cohesiveness refers to the tendency for members to be task committed to the group (Anwar, 2016), with a performance largely relying on team members' collective OCB and their attitude (Anwar, 2016; Maksum, Handoko, \& Fikriah, 2020). This implies that OCB influences the relationship between directive leadership and task performance.

\section{Supportive Leadership}

Supportive leadership is narrated as a form of group maintenance-oriented behaviour (Bateman \& Snell, 2011). Greg and Anne (1996) suggested that the leadership approach on initiating structure and consideration are aligned with two dimensions that described supportive leadership. These two dimensions were identified in 1945 Ohio Leadership studies (Stogdill, 1974). Moreover, supportive leadership has been distinguished from other leadership styles as a leadership behaviour that emphasises establishing good interpersonal relationships which help to create mutual trust and friendship between leader and subordinates. This leadership behaviour emphasises people-oriented or relational-oriented behaviour that prioritises employees' well-being (Stogdill, 1974), The aforesaid relationship is deemed to provide the cornerstone for enhancing a leader's effectiveness when a leader provides a supportive role to ensure tasks that have been structured could be efficiently performed by subordinates. Supportive leadership emphasises individualised attention on the followers by prioritising the leader's ability to motivate followers to achieve better organisational outcomes and could be considered as an essential leadership quality required for team leaders (Shin et al., 2016). Besides, this leadership behaviour could help to provide support for the followers' needs to motivate and coach them to accomplish a task more effectively, and for the long term development of each employee (Ogola, Sikalieh, \& Linge, 2017; Bass, 1990; House, 1971).

\section{Task Performance}

This study conceptualises task performance as job incumbents' behaviour that relates to individuals' ability to transform raw materials into goods and services specific to the job and core technical skills. (Cheng, Chiu, Chang, \& Johnstone, 2014). The key elements related to the task performance concept for this study are namely: knowledge, skills and ability, attitude, work itself, and commitment. An average human being dislikes works, shirks responsibility, needs to be controlled to work, prefers to be directed, desires security, and needs to be motivated to achieve self-fulfilment (McGregary, 1960). Thus, for effective management of employees in an organisational context, appropriate leadership skills approach is required. For effective administration (i.e. leadership), the skills approach in leadership is based on three skills, namely: technical, human, conceptual (Mumford et al., 2007; Katz, 1974). Technical skill refers to proficiency in an area of work. An effective leader (e.g. directive) must be competent and knowledgeable in his function in the organisation (Yulk, 2013) and able to guide and coach his subordinates, ultimately enhancing their performance. Research findings indicate that managerial coaching is an effective management technique that should be adopted to improve employee learning and 
performance effectively (Ratiu et al., 2017; Pousa et al., 2017). Leaders frequently are required to use different leadership styles simultaneously, to account for shortcomings individual leadership approaches in a certain situation, and to complement each other in managing their subordinates effectively for better performance.

\section{Motivation}

This study conceptualises motivation as the psychological processes that direct, energise, maintain action that drives employees towards intentional action on a job, task, role, or project (Campbell \& Pritchard, 1976). In its simplicity, it is the driving force behind an individual's actions. In this study, four sub-concepts are considered namely: Pay and Benefits; Recognition; Achievement, and Responsibility. Herzberg Two Factor Theory of Motivation (1966) concluded that two major factors: motivators (intrinsic factors) and hygiene factors (extrinsic factors) could influence employees' job satisfaction. According to Maslow's Hierarchy of Needs (1970), once an individual's physiological needs are satisfied, they are no more providing strong motivators for an individual to strive for higher levels of needs. These needs include better pay and benefits, conducive physical working conditions, job security, and others. Essentially, these job factors are categorised as the hygiene factors that symbolised physiological needs (Maslow, 1970). According to Herzberg (1966), these factors do not lead to positive satisfaction for the long-term and are extrinsic factors termed as dissatisfiers act to avoid dissatisfaction (Herzberg, 1966). Herzberg suggested that there were certain intrinsically motivational factors called satisfiers (motivators) that yield satisfaction and motivate employees to work harder. These motivational factors include recognition, achievement, and responsibility.

Motivation contributes to performance and could be classified broadly into two concepts, namely: extrinsic and intrinsic motivation (Bergstrom \& Mantinez, 2016; Legault, 2016). Extrinsic motivation is linked to satisfaction from satisfying physiological needs, such as monetary rewards, pay and benefits. Intrinsic motivation is associated with psychological factors such as satisfaction of being recognised and appreciated derived from meritorious individual's performance in work itself; increase in self-esteem upon of achievement; and honoured to be given responsibility at a higher level (Giancola, 2014; Herzberg, 1987; Maslow, 1970). Human basic needs include the physiological and safety needs that must be satisfied (Maslow, 1970) priors to attain the psychological state of needs. Herzberg (1987) further concluded that employers (managers) should be concerned about two major factors: motivators (intrinsic factors) and hygiene factors (extrinsic factors) to enhance the employees' job satisfaction. The employees would not be motivated when intrinsic (hygiene) factors are depleted (Yukl, 2013; Herzberg, 1987).

\section{Organisational Citizenship Behaviour (OCB)}

Originally, OCB was defined by Organ (1988) as a discretionary behaviour, not directly or indirectly explicitly recognised by the formal rewards system (Podsakoff et al., 2014). Morrison (1994) suggests that the boundary of employees' in-role and extra-role behaviours is not clearly defined because the roles in organisations are seldom fixed. This has prompted a revised definition of $O C B$ which can be defined as the merger of interpersonal and voluntary conducts that "supports the social and psychological environment in which task performance takes place" (Organ, 1997). A meta-analysis (Podsakoff, Mackenzie, Paine, \& Bachrach, 2013). indicates significant interaction effects between in-role performance (task performance) and extra-role performance ( $\mathrm{OCB} /$ contextual performance). Conceptually, $\mathrm{OCB}$ contributes to the 
effectiveness of work teams and organisations (Organ, 1988; Podsakoff et al., 2013). It represents the extra-role behaviours of employees in performing tasks that are distinguished from task performance behaviours which are in-role in nature (Werner, 2000).

This study defines the concept of OCB as largely discretionary employee behaviours which support task performance by enhancing a social and psychological work environment (Organ, 1997, p. 95). Researchers have identified more than 30 different dimensions of OCB distinguishable from merely task performance (Podsakoff et al., 2014). Due to the proliferation of these dimensions of behaviours, and by drawing from the work by researchers (LePine et al., 2002; Hoffman et al., 2007), this study focuses on four dimensions of OCB, namely: altruism, courtesy, conscientiousness, and sportsmanship. Altruism consists of discretionary behaviours that aim at helping individuals such as co-workers in resolving tasks or related problems in the work environment. Courtesy is referred to discretionary behaviours such as consulting and coordinating with other co-workers. Conscientiousness refers to individuals exhibiting task-related behaviour beyond the organisational requirement. Sportsmanship refers to behaviours of refraining from complaining about trivial matters or venting minor grievances.

\section{The Direct Effect of Leadership Styles on Task Performance Directive Leadership and Task performance}

Directive leadership is a form of behavioural, task performance-oriented leadership approach that centralises on goal setting and role clarification (Bateman \& Snell, 2011; Yukl, Gordon, \& Taber, 2002; House, 1971). In organisational institutions, this implies that directive leadership style has its direct effect on employee task performance behaviour. According to House' PathGoal Theory of leadership (House, 1971) for a leader to be effective, he must possess knowledge, skills, and abilities related to the task and work environment to guide subordinates through the right path to achieve their goals. Northouse (2013) suggested that a person's skills and abilities could be learned and developed. Researchers' findings further suggested that the employees' learning and performance effectiveness could be improved with effective managerial coaching practices (Ratiu et al., 2017; Pousa et al., 2017). In addition, a leader is often regarded as a role model to his subordinates within the organisation, with part of his/her responsibilities is to act as a mentor and coach to his/her subordinates

Directive leadership style is frequently associated with an autocratic and coercive style that could result in an adverse reaction from the subordinates and deters trust with their leadership (Rawat \& Lyndon, 2016; Blau, 1964). Researchers' findings have suggested that employee learning and performance effectiveness could be improved with effective managerial coaching practices (Ratiu et al., 2017; Pousa et al., 2017). A directive leader with good interpersonal skills would be an advantageous trait that would influence employee cognitions, choices, and behaviours (Markovic \& Ljajic, 2016; Yukl, 2013; Katz, 1974). Consequently, a directive leader with a high level of human skills would be more adaptable to subordinates' ideas that could support them for better organisational outcomes (Markovic \& Ljajic, 2016; Katz, 1974). This study conceptualises proposition:

$P 1$ : There is a positive and significant relationship between directive leadership and task performance.

\section{Supportive Leadership and Task Performance}


To accomplish a supportive leadership role, the organisation's owners, managers, and supervisors should provide related resources that allow subordinates to complete tasks with minimum supervision over time, with the long-term development of employees in mind. This is aligned with two key elements in the concept of supportive leadership (Stogdill, 1974). Although task delegation remains an integral part of supportive leadership, supportive leaders provide support for the employees' needs, motivate and coach them until they have adequate self-confidence to accomplish the task themselves.

From the organisation's human resources management perspective, the owners' role as leaders and adopting a supportive leadership approach would generally be perceived by employees as an organisational supportive gesture. According to organisational support theory (Eisenberger et al., 2016), workers' perception of lack of organisational support would be highly likely to be construed as a reflection of the organisation's indifferent attitude towards workers' values and well-beings. Perceived organisational support (POS) is widely accepted as the organisation's contribution to positive reciprocity dynamic with employees, as employees tend to reciprocate received rewards and favourable treatment with their enhanced performance. Workers who are valued, recognised, and appreciated by their superior and organisation would help to enhance their self-esteem state that consolidates their self-confidence in taking up difficult tasks and challenges as reciprocity of high POS (Zhong et al., 2016). High POS would lead to increased employee performance (Eisenberger et al., 2016). Yukl (2013) has provided some guidelines to the supportive leaders for managing subordinates effectively, which include bolstering the subordinates' self-esteem and confidence. Supportive leaders (e.g. supervisors) could provide verbal encouragement to a worker facing a difficult job problem. Research indicates that supportive leadership helps to reduce employee acute stressors and improve social cohesion (Sharma \& Pearsall, 2016). All these outcome variables (e.g. employee stress, job dissatisfaction, and turnover intention) would likely lower employee productivity level and hence their task performance behaviour. This study conceptualises proposition 2:

$P 2$ : There is a positive and significant relationship between supportive leadership and task performance.

\section{Explicating the Influencing Role of Key Concepts on Leadership Styles--Task Performance Relationship}

The Influencing role of Motivation on Directive Leadership-Task Performance relationship Motivation provides momentum that drives employees to perform tasks willingly and effectively, thus enhances the organisation's effectiveness and competence (Parashar, 2016). A motivated workforce is widely accepted to be more innovative, creative, ambitious, responsible attitude and with altruistic behaviour that contributes to enhanced task performance behaviours and elevated productivity (Parashar, 2016). Motivation could be classified broadly into two concepts, namely: extrinsic and intrinsic motivation (Bergstrom \& Mantinez, 2016; Legault, 2016). Extrinsic motivation is linked to the satisfaction of physiological needs, such as monetary rewards, pay and benefits. Intrinsic motivation is associated with psychological factors such as satisfaction of being recognised and appreciated which is derived from meritorious individual's performance in work itself; increase in selfesteem upon of achievement; and honoured to be given responsibility at a higher level (Giancola, 2014; Herzberg, 1987; Maslow, 1970). According to Maslow (1970), once an individual's basic needs (physiological needs) are satisfied, they are no more providing a strong motivator for an individual to strive for higher levels of needs. Herzberg (1987) further 
concluded that leaders should emphasise both intrinsic factors and extrinsic factors to enhance the employees' job satisfaction.

The Path-Goal Theory of Leadership (House, 1971) opined that the leader's most practised style is to be utilised as a motivational mechanism to get subordinates to achieve goals satisfactorily, and adaptability of different leadership behaviours would reinforce the level of acceptance of a leader by the subordinates (Polston-Murdoch, 2013). In other words, the subordinates would be motivated to perform better if their leader's style or behaviour could help them to meet their needs, expectations, and satisfaction, which represent the motivational factors for them in the obtainment of their daily task activities (Parashar, 2016; House, 1971). Although research findings have suggested that the directive style does have its impact on employee task performance (Kim \& Egan, 2013), a directive leader's strict instruction and guidelines deliberated to the subordinates sometimes can be construed as an autocratic and coercive approach. Evidence from past researches indicated that abusive supervision and supervisor-directed aggression are strongly related, albeit different organisational settings, cultures, and research designs (Lian, Brown, Ferris, Liang, Keeping, \& Morrison, 2014; Liu, Kwan, Wu, \& Wu, 2010). Under these circumstances, directive leaders should focus on ensuring that their subordinates (employees) are extrinsically and intrinsically motivated (Herzberg, 1987; Maslow, 1954). The current study (Bergstrom \& Martinez, 2016) suggested that intrinsic motivation and extrinsic motivation have influences on the psychological aspects of employee engagement, with extrinsic motivation occupies less influence but remains part of the whole motivational mechanism. Employee engagement was found to have a positive impact on the performance of organisations, employees' productivity level and higher retention rates (Osborne \& Hammoud, 2017; Musgrove, Ellinger, \& Ellinger, 2014).

Thus, this study proposes that the adverse directive characteristics could be mitigated by adopting various motivational strategies tactfully to mediate the relationship between directive style and employee task performance behaviour. The directive leadership style with a situational approach, in addition to motivational factors, could prove to be a meritorious leadership approach of practicality and appropriateness. This study proposes that:

P3: There is a positive and significant mediating effect of motivation on the relationship between directive leadership and task performance.

\section{The Influencing role of OCB on directive Leadership-Task Performance Relationship}

OCB can be defined as the merger of interpersonal and voluntary conducts that "supports the social and psychological environment in which task performance takes place" (Organ, 1997). Interpersonal conducts refer to interactions among individuals that build relationships in the workplace through economic exchange and social exchange (Blau, 1964). According to the Social Exchange Theory (Blau, 1964) and the Norm of Reciprocity (Gouldner, 1960), social exchange relationships between employees and organisations would become stronger when both parties are willing to provide and exchange resources valuable to them. The perceived fair and beneficial treatment extended from employers to employees would be reciprocated by employees' loyalty and dedication towards the organisation (Strenitzerová \& Achimský, 2019; Eisenberger et al., 2001). The social exchange mechanism could provide a strong basis for establishing an interpersonal relationship based on mutual trust between employees and their organisation. Siqueira (2003) suggested that social exchange would be based on mutual trust, a sense of personal obligations, gratitude, and confidence. In addition, findings from research (Lau et al., 2014) indicated that positive reactions from employees could happen 
when they feel that they are being trusted by their supervisors in the workplace. Thus, the prospective influence of $\mathrm{OCB}$ on organisational outcomes should not be disregarded.

According to McGregor's Theory X and Theory $Y(1960)$, Theory $X$ managers assume that workers dislike work and will find excuses to avoid it; require to be supervised constantly; prefer to be directed; desire security; and need to be motivated to achieve self-fulfilment. Primarily, it is difficult to envisage the psychological mood state of workers, whereby it could be influenced by their leaders' characteristics and the leadership styles they adopt. A metaanalysis on OCB (Podsakoff et al., 2013) found that directive leadership behaviour, that has been identified by Path-Goal Theory of Leadership (House, 1971) as a role clarification and specification of procedures behaviour, is positively related to altruism, conscientiousness, courtesy and sportsmanship/ These four elements are regarded as important dimensions of OCB. Additionally, co-operation and helping others in the workplace are prosocial gestures that reflect the individuals' selflessness and practice of concern for the welfare and works' needs of others (e.g. co-workers and supervisors). The practice of such prosocial behaviour is analogous to altruism and courtesy which are two important dimensions of OCB.

It is widely perceived that the directive leadership style is more inclined towards autocratic or abusive nature. From the norm of reciprocity perspective, employees could resort to evade from assuming extra-role responsibility and merely performing their tasks within contractual obligations to avoid punishment. Mittal and Elias (2016) opined that leaders in individualistic cultures emphasise coercive power. Similarly, a leader in a high power distance culture tends to act autocratically (Mittal \& Elias, 2016), both of which are normally associated with a directive and/or autocratic leadership style and could be obnoxious to employees because of its offensive characteristics, thus resulting in difficulty for the aforesaid leadership style to be associated with employees' OCB.

Extrinsic motivators, such as pay and benefits, are the basic physiological needs of employees in general. However, these are only temporarily effective, and unfavourable working environments and conditions would result in employees' dissatisfaction which tends to demoralise workers (Agbenyegah, 2019; Sivalogathasan \& Senanayake 2016). It has been noted that intrinsic factors are concerned with work itself that is related to the psychological mood state of individuals. In that respect, leaders must secure respect from their followers. The reason is that employees tend to look up to their leader as a role model for their dependency and assistance when they face challenges in resolving day-to-day problems. Under that circumstances, leaders will earn respect from their subordinates for their skills and competency in guiding and directing them out of trouble waters (Şenturan, Çetin, \& Demiralay, 2017) thus enhancing individual effectiveness (Dong et al., 2017). This helps to boost employee self-esteem and self-efficacy, which would develop into a mutual trust relationship between the two parties. The relationship of familiarity between leader and employees would dually facilitate fluid communication and feedbacks. In line with the thought, employees would perceive that their performance is being recognised and appreciated and are likely to exhibit discretionary extra-role behaviours (i.e. OCB). Thus, conceptually it is assumed that a directive leadership approach could further enhance employee task performance behaviour if it is being adopted strategically. This study proposes that:

P4: There is a positive and significant mediating effect of OCB on the relationship between directive leadership and task performance.

The Influential Role of Motivation on Supportive Leadership-Task Performance Relationship 
Industrial and organisational psychology research suggests that effective and successful leaders must be supportive of their subordinates by being good listeners, attentive and sympathetic (Surji, 2015; Schultz, \& Schultz, 2009). The influential role of motivation on the relationship between supportive leadership and task performance is based on the notion that a high level of motivation and performance could be achieved with effective collaboration between the leader and followers (Surji, 2015). It follows that for effective collaboration between the leader and followers to occur, a supportive leadership approach could be adopted for building an effective interpersonal relationship (Yukl, 2013). Supportive leadership contains two attributes, namely job, and relationship (Rooney \& Gottlieb, 2007). Job attribute is concerned with how the leader and/or management could guide and motivate their subordinates to accomplish their task. This attribute could include perceived supervisor support on the employees' training for their development needs that motivate to enhance performance and productivity (Park et al., 2017). Relationship attribute is related to peopleoriented behaviour for which the leader is to play a supportive role that involves empathising workers' needs, shared purpose, social value, voice, processes in coaching and guiding them on their work (Jay et al., 2007).

Recent studies suggested that a supportive leadership climate would promote social cohesion for followers (Sharma \& Pearsall, 2016). Social cohesion includes elements of friendship, emotional closeness, liking, and caring among team members (Griffith, 2007; Sharma \& Persall, 2016). High quality of the relationship between supervisor-subordinate could contribute to amicable and successful workplace inclusion, that is, it helps to cultivate the employee sense of belonging to the workplace (Gates, 1993), as well as it nurtures mutual trust, respect, affection, loyalty (Graen \& Uhl-Bien, 1995). These elements are motivating factors that act as intrinsic motivators that prevent dissatisfaction from being generated among followers (Herzberg, 1987). In supportive leadership, the managers will delegate tasks, collaborate by working through the tasks with their subordinates, and train them until they have acquired skills and abilities to perform tasks on their own. It entails a long-term development process for the employees. The managers should be good listeners, be sensitive and empathise with their employees' emotional problems. In the supportive leadership influencing process, the followers derive their intrinsic motivation through the satisfaction of attainment of self-confidence, self-esteem, self-reliance, stress-relief work environment psychological states. All these consequences are emanated from the perceived leader's support which transpires and impresses onto the employees' mentality that they are being recognised and appreciated by the organisation. In the analysis of various concepts above, it can be explicated that motivation does have its role in influencing the relationship between supportive leadership and task performance. Thus, this study proposes that:

$P 5$ : There is a positive and significant mediating effect of motivation on the relationship between supportive leadership and task performance.

\section{The Influential role of OCB on Supportive Leadership-Task Performance Relationship}

Podsakoff et al (2013) has found significant interacting effects between in-role performance (task performance) and extra-role performance (OCB/contextual performance). Conceptually, it is generally accepted that OCB contributes to the effectiveness of work teams and organisations (Organ, 1988; Podsakoff et al., 2013). It represents the extra-role behaviours of employees in performing tasks that are distinguished from task performance behaviours which are in-role in nature (Werner, 2000). It is worth noting that employees are not obliged to engage in extra-role behaviours contractually. 
Several antecedents are associated with the employees' willingness to engage themselves in OCB in the workplace, such as personality/traits of an individual (Organ \& Ryan, 1995; Borman et al., 2001); perceptions of fairness (Bateman \& Organ 1983; Organ \& Ryan, 1995; Tepper \& Taylor, 2003); leadership qualities and interpersonal relationship between leader and employee (Podsakoff, Mackenzie, \& Bommer, 1996); motivational theories (Kemery, Bedeian, \& Zacur, 1996). Path-Goal Theory (House, 1971) indicated that leaders who employ a supportive leadership style with friendly and approachable behavioural characteristics would exhibit acceptable leadership qualities and interpersonal relationship characteristics that invigorate their employees' willingness to engage OCB. An effective leader must possess good listening skills, be sensitive and empathetic with subordinates' feelings, allowing a conduit for them to vent their emotion and problems. In sum, the preceding discussion reveals that the supportive leadership approach has several exceptional characteristics antecedent to followers' OCB which predicts task performance. Thus, this study proposes that:

P6: There is a positive and significant mediating effect of OCB on the relationship between supportive leadership and task performance.

\section{Conceptual Framework}

This study intends to examine the influence of employees' motivation and OCB on the relationship between leadership styles (directive and supportive) and task performance. This could be answered when the relationships between leadership styles (independent variables), motivation and OCB; and task performance (dependent variable). are analysed simultaneously.

Figure 1: Conceptual Framework of the study

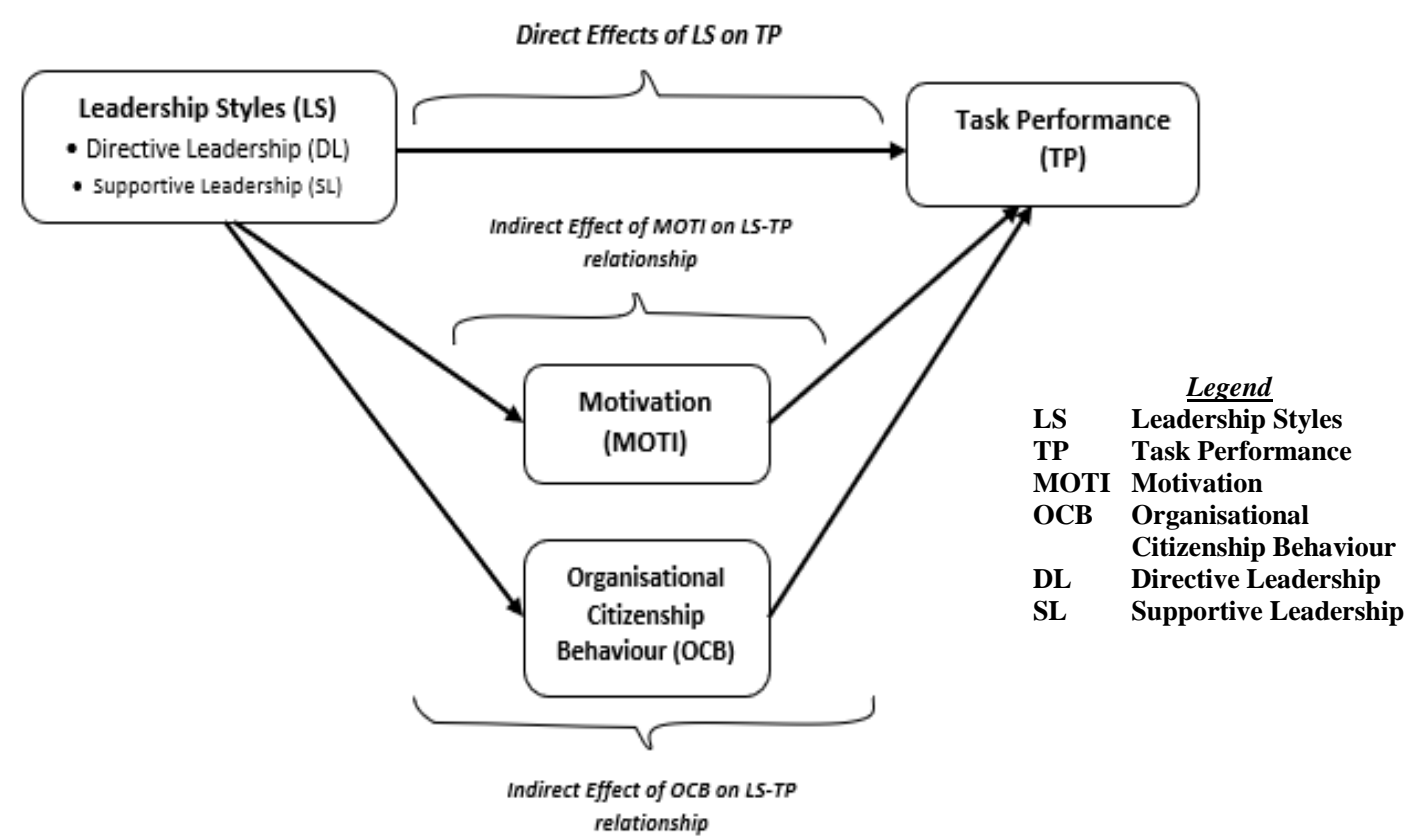

Source: Adapted from Holbert \& Stephenson (2003)

From the literature review, a conceptual framework is formulated as shown in Figure 1 . The conceptual framework is adapted from Holbert and Stephenson (2003) by adding one independent concept (variable). Specifically, this study hypothesises that OCB and motivation are antecedents that act as mediating roles between directive leadership and task performance, and between supportive leadership and task performance. Structural Equation 
Modeling (SEM) with AMOS graphical-based statistical analytical software would be employed in analysing these interrelationships between the key concepts (variables) simultaneously (Gallagher et al., 2008).

\section{Methodology}

This study intends to use survey research which provides a quantitative description of 'trends, attitudes, or opinions of a population by studying a sample of that population' (Creswell 2018). This survey research will include cross-sectional studies which are designed to look at a variable in which data are collected from selected individuals at a single point in time (Mills \& Gay, 2016). Administering questionnaires will be used for data collection. The rationale of using this survey method is based on the following reasons: data collected from survey questionnaires (measuring instrument) can be obtained from a large number of respondents over a vast area (Best \& Kahn, 2006); generalisability of findings on total population; and due to time and cost constraints (Sekaran \& Bougie, 2013). The target population of this study is the operational level employees working in quarry organisations within the umbrella of the stone-mining industry in Malaysia. Researchers suggested that when analysing data using Structural Equation Modeling (SEM), the determination of sample size could be based on the number of latent constructs (key concepts) in the conceptual model and thus suggested that sample size for this study is in the range of 150-400 (Hair, Black, Babin, \& Anderson, 2010). The sampling process consists of four (4) steps: define population and sampling technique; define the sampling frame; determine the sampling design; and executing the sampling process (Sekaran \& Bougie, 2013). The sampling technique uses a stratified sampling method which divides the population into separate groups based on geographical zones. Quarries from each geographical zone would be selected randomly. The target population of this study would be further stratified at operation level employees working in their respective quarry organisations within the umbrella of the stone-mining industry in Malaysia. The quarrying organisations in Malaysia will be the sampling frame. Probability sampling design would be used and executed, in which elements in the population would have equal chances to be selected as sample subjects (Sekaran \& Bougie, 2013).

Data collected will be analysed by statistical techniques using SPSS for descriptive statistics, and Structural Equations Modeling-Analysis of Moment Structures (SEM-AMOS) for analysing the interrelationships among the key concepts for this study (Hair et al, 2010). The survey questionnaire would be used to obtain information about socio-demographics and respondents' attitudes and opinions. The questionnaire will be designed to be self-completed independently by the respondents. The questions will be adopted and adapted from questionnaires used by other researchers. To ensure that the measuring instrument is reasonably good, it must demonstrate high reliability, which is the test of its internal consistency. Subsequently, examining the validity of the measuring instrument is necessary to ensure that the various measuring items in the instrument (questionnaire) would be able to tap the concepts set up to measure. The validity tests will include tests for face validity, content validity and construct validity (Sekaran \& Bougie, 2013). A pilot test will be carried out purposively to increase the likelihood of face validity of the instrument, that is, the instrument should be able to measure what it is supposed to measure (Awang \& Mohamad, 2016). The intended pilot study aims to determine the reliability of the survey instrument to ensure its internal consistency in measurement, denoted by Cronbach's alpha $\geq 0.6$ as an acceptable value of instruments reliability (Gallagher et al, 2008). This pilot study is important for obtaining accurate results during the subsequent field study. 
The validity of content validity would be ascertained when the instrument's contents are adequately and proportionately representing different elements of the concept or domain (Sekaran \& Bougie, 2013), and can also be validified by experts in the field of this study. Before SEM analysis, the content validity will first be assessed by conducting Exploratory Factor Analysis (EFA) on data collected from a pilot study, for which measuring items with low factor loading or redundancy would be deleted before proceeding to further analysis. Construct validity will be ascertained by conducting Confirmatory Factor Analysis (CFA) during the data analysis process to be performed by IBM-SPSS SEM-AMOS graphically based modelling statistical software. The hypothesised model developed for this study will be assessed by using SEM-AMOS for its validity as a theory fitting model.

\section{Discussion and Conclusion}

The motivation of this study is the desire to face the challenge of solving the unresolved practical and managerial problems facing construction and quarrying industries in Malaysia. In addition, the authors desire to explore the effect of lesser-researched leadership styles (directive and supportive) on workers' task performance behaviours. This study aims to assist practitioners in understanding the importance of selecting appropriate leadership styles for managing their workforce. This study aims to contribute to the development of a new hypothesised model. The validity of this hypothesised model as a theory fitting model could contribute to the body of knowledge in leadership development.

In Malaysian construction and quarrying sectors, poor employee task performance behaviours could have contributed to the increase in fatal industrial accidents at the workplace since 2018. Maintaining a balance of different leadership styles is imperative for resolving these managerial issues. The situation is worrisome as construction and quarrying sectors are the main economic sectors that contribute to the national gross domestic product (GDP) growth. In previous studies, the directive and supportive leadership styles are two leadership approaches found to complement each other, enhance employee performance and contribute to the organisational outcomes positively. Conceptually, the impact of leadership styles on employee task performance relationships would be fortified by the interventions of motivation and OCB as the two mediating factors. In the future, it is hoped that this research will add to an improved organisational managerial blueprint, notably in adopting appropriate leadership styles in managing the organisational workforce. Conversely, if the ill effects cannot contend with this study, more research and innovation are needed for seeking other strategies to improve employee task performance behaviour.

\section{Acknowledgements}

Special appreciation to Cluster of Business and Management (CBM), and Research and Project Management Unit (RPMU) of Open University Malaysia (OUM), Malaysia.

\section{References}

Agbenyegah, G. K. (2019). Effect of financial and non-financial rewards on employee motivation in financial institution in Ghana. International Journal of Innovative Research \& Development, 8(8), 121- 130.

Anwar, K. (2016). Working with group-tasks and group cohesiveness. International Education Studies, 9(8), 105-111. 
Aris, A., \& Kamarudin, M. F. (2009). The impact of path-goal leadership behavior group on group cohesiveness: A Japanese electronics company and Singaporean electronic company in Johor. Journal of Human Capital Development, 2(1), 1-11.

Awang, Z., \& Mohamad, M. (2016). Postgraduate research proposal: A step-by-step guide in writing proposal for postgraduate students. MPWS Rich Publication Sdn Bhd, Selangor, Malaysia.

Basit, A., Sebastian, V., \& Hassan, Z. (2017). Impact of leadership style on employee performance: A case study on a private organization in Malaysia. International Journal of Accounting and Business Management, 5(2), 112- 130.

Bass, B. M. (1990). Bass and Stogdill's handbook of leadership: Theory research, and managerial applications (3rd ed.). New York: Free Press.

Bateman, T. S., \& Organ, D. W. (1983). Job satisfaction and the good soldier: The relationship between affect and employee "citizenship". Academy of Management Journal, 26(4), 587-595.

Bateman, T. S., \& Snell, S. A. (2011). Management: Leading \& collaborating in a competitive world (pp. 454-464). McGraw-Hill/Irwin, The McGraw Hill Companies, Inc.

Bergström, E., \& Martinez, M. G. (2016). The influence of intrinsic and extrinsic motivation on employee engagement: A qualitative study of the perceptions of managers in public and private sector organizations [Degree project. Umeå University].

Best, J., \& Kahn. (2006). Research in education (10 th ed.). Boston. Allyn \& Bacon.

Blau, P. M. (1964). Exchange and power in social life (13th ed.). New York. Bodies of two foreign workers buried in landslide at quarry found. (2014, September 8). Bernama, Astroawani. https://tinyurl.com/y9jwemqa [Open in new window]

Campbell, D. J., \& Pritchard, R. (1976). Motivation theory in industrial and organizational psychology. In M. D. Dunnette (Ed.), Handbook of industrial and organizational psychology (pp. 63-130). Chicago: Rand McNally.

Cheng, J. W., Chiu, W. L., Chang, Y. Y., \& Johnstone, S. (2014). Do you put your best foot forward? Interactive effects of task performance and impression management tactics on career outcomes. The Journal of Psychology, 148(6), 621-640.

Creswell, J. W. (2018). Research design: Qualitative, quantitative, and mixed methods approaches ( $5^{\text {th }}$ ed.). SAGE Publications, Inc.

Dong, Y. T., Bartol, K. M., Zhang, Z. X., \& Li, C. W. (2017). Enhancing employee creativity via individual skill development and team knowledge sharing: Influences of dual-focused transformational leadership. Journal of Organizational Behavior, 38(3), $439-458$.

Eisenberger, R., Armeli, S., Rexwinkel, B., Lynch, P. D., \& Rhoades, L. (2001). Reciprocation of perceived organizational support. Journal of Applied Psychology, 86(1), 42-51.

Eisenberger, R., Malone, G. P., \& Presson, W. D. (2016). Optimizing perceived organizational support to enhance employee engagement. Society for Human Resource Management and Society for Industrial and Organizational Psychology (pp. 3-22).

Flying rocks from quarry blasting. (2007). The Star: Community. https://tinyurl.com/yc6jyl8y [Open in new window]

French, J. R. P., \& Raven, B. (1959). The bases of social power. In D. Cartwright (Ed.). Studies in social power (pp. 150-167). University of Michigan.

Gallagher, D., Ting, L., \& Palmer, A. (2008). A journey into the unknown: Taking the fear out of structural equation modeling with AMOS for the first-time user. The Marketing Review, 8(3), 255-275. 
Gates, L. B. (1993). The role of the supervisor in successful adjustment to work with a disabling condition: Issues for disability policy and practice. Journal of Occupational Rehabilitation, 3(4), 179-190.

Giancola, F. L. (2014). Should HR professionals devote more time to intrinsic rewards? Compensation \& Benefits Review, 46(1), 25-31

Gouldner, A. W. (1960). The norm of reciprocity: A preliminary statement. American Sociological Review, 25(2), 161-178.

Graen, G. B., \& Uhl-Bien, M. (1995). Relationship-based approach to leadership: Development of leader-member exchange (LMX) theory of leadership over 25 Years: Applying a multilevel multi-domain perspective. The Leadership Quarterly, 6(2), 219-247.

Greg, R. O., \& Anne, C. (1996). "Employee Creativity: Personal and Contextual Factors at Work", The Academy of Management Journal, Vol 39, No. 3 (June 1996) pp. 607-634.

Griffith, J. (2007). Further considerations concerning the cohesion-performance relation in military settings. Armed Forces and Society, 34(1), 138-147.

Hair, J. F., Black, W. C., Babin, B. J., \& Anderson, R. E. (2010). Multivariate data analysis (7 ${ }^{\text {th }}$ ed.). Englewood Cliffs, NJ: Prentice Hall.

Herzberg, F. (1966). Work and the nature of man. Cleveland, $\mathrm{OH}$ : World Publishing Company. Herzberg, F. (1987). One more time: How do you motivate employees? Harvard Business Review, 1-16.

Hoffman, B. J., Blair, C. A., Meriac, J. P., \& Woehr, D. J. (2007). Expanding the criterion domain? A quantitative review of the OCB literature. Journal of Applied Psychology, 92(2), 555566.

Holbert, R. L., \& Stephenson, M. T. (2003). The importance of indirect effects in media effects research: Testing of mediation in structural equation modeling. Journal of Broadcasting and Electronic Media, 47(4), 556-572.

House, R. J. (1971). A path goal theory of leader effectiveness. Administrative Science Quarterly, 16(3), 321-339.

Ibrahim, M. A., \& Aslinda, A. (2013). Relationship between organizational commitment and citizenship behavior (OCB): At government-owned corporation companies. Journal of Public Administration and Governance, 3(3), 1-8.

Idris, S. M. M. (2008). Peraks quarry death toll way too high. Malaysiakini. https://www.malaysiakini.com/letters/65490

Itiola, K. O., Odebiyi, I. I., \& Alabi, E. (2014). Empirical study of impact of organizational citizenship behaviour dimensions on job satisfaction among administrative staff of Osun state owned tertiary institutions, Nigeria. International Journal of Academic Research in Business and Social Sciences, 4(8), 264-274.

Jay, B. C., Paul, E. T., \& Jennifer, A. M. (2007). Shared leadership in teams: An investigation of antecedent conditions and performance. Academy of Management Journal, 50(5), 1217-1234.

Katz, D. (1974). The motivational basis of organizational behaviour. Behavioral Science, 9(2), 131-146.

Kemery, E. R., Bedeian, A. G., \& Zacur, S. R. (1996). Expectancy-based job cognitions and job affect as predictors of organizational citizenship behaviors. Journal of Applied Social Psychology, 26(7), 635-651.

Kim, S., \& Egan, T. (2013). Invited reaction: The contrasting effects of coaching style on task performance: The mediating roles of subjective task complexity and self-set goal. Human Resource Development Quarterly, 24(4), 459-468. 
Kramer, M., Page, L., \& Klemic, G. (2018). Evolving leadership: New clues and cues towards environment and context. Journal of Leadership Studies, 12(4), 82-85.

Kumar, D. M., \& Chung, J. F. (2019). Impact of leadership and personality on organisational commitment- Malaysian SMEs study. Nóesis. Revista de Ciencias Socialesy Humanidades 4(17), 115 - 128.

Kuranchie-Mensah, E. B., \& Amponsah-Tawiah, K. (2015). Employee motivation and work performance: A comparative study of mining companies in Ghana. Journal of Industrial Engineering and Management, 9(2), 255-309.

Lau, D. C., Lam, L. W., \& Wen, S. S. (2014). Examining the effects of feeling trusted by supervisors in the workplace: A self-evaluative perspective. Journal of Organizational Behavior, 35(1), 112-127.

Legault, L. (2016). Intrinsic and extrinsic motivation. Encyclopedia of Personality and Individual Differences. Springer International Publishing AG 2016V. Zeigler-Hill, T.K. Shackelford (eds.).

LePine, J. A., Erez, A., \& Johnson, D. E. (2002). The nature and dimensionality of organizational citizenship behavior: A critical review and meta-analysis. Journal of Applied Psychology, 87(1), 52-65.

Lian, H., Brown, D. J., Ferris, D. L., Liang, L. H., Keeping, L. M., \& Morrison, R. (2014). Abusive supervision and retaliation: A self-control framework. Academy of Management Journal, 57(1), 116-139.

Liu, J., Kwan, H. A. K., Wu, L., \& Wu, W. (2010). Abusive supervision and subordinate supervisor directed deviance: The moderating role of traditional values and the mediating role of revenge cognitions. Journal of Occupational and Organizational Psychology, 83(4), 835-856.

Lor, W., \& Hassan, Z. (2017). The influence of leadership on employee performance among jewellery artisans in Malaysia. International Journal of Accounting \& Business Management, 5(1), 14-33.

Lorinkova, N. M., Pearsall, M. J., \& Sims, Jr. H. P. (2013). Examining the differential longitudinal performance of directive versus empowering leadership in teams. Academy of Management Journal, 56(2), 573-596.

Maksum, I., Handoko, T. H., \& Fifriah, N. L. (2020). Group cohesiveness on performance: Mediating effect of collective organization citizenship behavior. Jurnal Manajemen, 24(3), 443-459.

Markovic, Z., \& Ljajic, S. (2016). Leadership skills and training [Paper presentation]. Eleventh international scientific conference: Knowledge in practice, Bansko, Bulgaria.

Martin, S. L., Liao, H., \& Campbell, E. M. (2013). Directive versus empowering leadership: A field experiment comparing impacts on task proficiency and proactivity. Academy of Management Journal, 56(5), 1372-1395.

Maslow, A. H. (1970), Motivation and personality. Harper, New York, NY.

McGregor, D. (1960). The human side of enterprise. McGraw-Hill, 1960, annotated edition, McGraw-Hill, 2006.

Mills, G. E., \& Gay, L. R. (2016). Educational research: Competencies for analysis and applications (11 $11^{\text {th }}$ ed.). Boston, Person.

Mintzberg, H. (1983). Power in and around organizations. Englewood Cliffs, NJ: Prentice Hill. Mittal, R., \& Elias, S. (2016). Social power and leadership in cross-cultural context. Journal of Management Development, 35(1), 58-74. 
Morrison, E. W. (1994). Role definitions and organizational citizenship behaviour: The importance of the employee perspective. Academy of Management Journal, 37(6), 1543-1567

Mumford, T. V., Campion, M. A., \& Morgeson, F. P. (2007). The leadership skills strataplex: Leadership skill requirements across organizational levels. The Leadership Quarterly, 18(2), 154-166.

Musgrove, C., Ellinger, A. E., \& Ellinger, A. D. (2014). Examining the influence of strategic profit emphases on employee engagement and service climate. Journal of Workplace Learning, 26(3-4), 152-171.

Mwaisaka, D. M., K'Aol, G., \& Ouma, C. (2019). Influence of directive and supportive leadership styles on employee job satisfaction in commercial banks in Kenya. International Journal of Research in Business and Social Science, 8(6), 168-174. Nielsen, P. A., Boye, S., Holten, A. L., Jacobsen, C. B., \& Andersen, L. B. (2019). Are transformational and transactional types of leadership compatible? A two-wave study of employee motivation. Public Administration, 97(2), 413-428.

Northouse, P. (2013). Leadership theory and practice. Thousand Oaks: Sage Publications, Inc.

Ogola, M. G. O., Sikalieh, D, \& Linge, T. K. (2017). The influence of intellectual stimulation leadership behaviour on employee performance in SMEs in Kenya. International Journal of Business and Social Science, 8(3). 89-100.

Organ, D. W. (1988). Organizational citizenship behaviour: The good soldier syndrome. Lexington Books, Lexington, MA.

Organ, D. W. (1997). Organizational citizenship behaviour: Its construct clean-up time. Human Performance, 10(2), 85-97.

Organ, D. W., \& Ryan, K. (1995). A meta-analytic review of attitudinal and dispositional predictors of organizational citizenship behaviour. Personnel Psychology, 48(4), 775802.

Osborne, S., \& Hammoud, M. S. (2017). Effective employee engagement in the workplace. International Journal of Applied Management and Technology 16(1), 50-67.

Parashar, B. K. (2016). Significance of Theory Z in Indian scenario. International Journal of Management and Social Sciences Research, 5(2), 8-16.

Park, S., Kang, H. S., \& Kim, E. J. (2017). The role of supervisor support on employee's' training and job performance: An empirical study. European Journal of Training and Development, 42(1-2), 57-74.

Podsakoff, P. M., Mackenzie, S. B., \& Bommer, W. H. (1996). Transformational leader behaviors and substitutes for leadership as determinants of employee satisfaction, commitment, trust, and organizational citizenship behaviors. Journal of Management, 22(2), 259-298.

Podsakoff, P. M., Mackenzie, S. B., Paine, J. B., \& Bachrach, D. G. (2013). Organizational citizenship behaviours: A critical review of the theoretical and empirical literature and suggestions for future research. Journal of Management, 26(3), 513-563.

Podsakoff, N. P., Podsakoff, P. M., MacKenzie, S. B., Maynes, T. D., \& Spoelma, T. M. (2014). Consequences of unit-level organizational citizenship behaviors: $A$ review and recommendations for future research. Journal of Organizational Behavior, 35(S1), S122, S23-S157.

Polston-Murdoch, L. (2013). An investigation of path-goal theory, relationship of leadership style, supervisor-related commitment, and gender. Emerging Leadership Journeys, 6(1), 13-44. 
Pousa, C., Mathieu, A., \& Trepanier, C. (2017). Managing salesperson performance through coaching: The moderating role of selling experience. In Marketing at the confluence between entertainment and analytics (pp. 653-657). Springer, Cham.

Rahman, N. A., Mansor, M. A., \& Ismail, A. R. (2015). Accidents in mining and quarry sites: Rate of occurrences and causes. International Journal of Creative Future and Heritage (TENIAT), 3(2), 23-32. Official URL:http://teniat.umk.edu.my/images/TENIATVol3Issue220...

Ratiu, L., David, O. A., \& Baban, A. (2017). Developing managerial skills through coaching: Efficacy of a cognitive behavioural coaching program. Journal of Rational-Emotive \& Cognitive-Behavior Therapy, 35(1), 88-110.

Rawat, P. S., \& Lyndon, S. (2016). Effect of paternalistic leadership style on subordinate's trust: An Indian study. Journal of Indian Business Research, 8(4), 264 - 277.

Rooney, J. A., \& Gottlieb, B. H. (2007). Development and initial validation of a measure of supportive and unsupportive managerial behaviors. Journal of Vocational Behavior, 71(2), 186-203.

Schultz, D. P., \& Schultz, S. E. (2009). Psychology and work today: An introduction to industrial and organizational psychology (10 ${ }^{\text {th }}$ ed.). New York, Routledge.

Sekaran, U., \& Bougie, R. (2013). Research methods for business: A skill-building approach ( $6^{\text {th }}$ ed.). John Wiley \& Sons Ltd.

Şenturan, S., Çetin, C., \& Demiralay, T. (2017). An investigation of the relationship between role ambiguity, role conflict, workplace friendship, and loneliness at work. International Journal of Business and Social Science, 8(5), 60-68.

Shah, M. F. (2013). One killed in quarry site explosion. The Star. https://tinyurl.com/y7t3whsg [Open in new window]

Sharma, P. N., \& Pearsall, M. J. (2016). Leading under adversity: Interactive effects of acute stressors and upper-level supportive leadership climate on lower-level supportive leadership climate. The Leadership Quarterly, 27(6), 856-868.

Shin, Y., Oh, W. K., Sim, C. H., \& Lee, J. Y. (2016). A multilevel study of supportive leadership and individual work outcomes: The mediating roles of team cooperation, job satisfaction, and team commitment. The Journal of Applied Business Research, 32(1), 55-70.

Siqueira, K. (2003). Participation in organized and unorganized protests and rebellions. European Journal of Political Economy, 19(4), 861-874. Sivalogathasan, V., \& Senanayake, S. A. D. (2016, August). Achievement will motivate: The impact of nonfinancial rewards on motivation of employees in the selected private company. commerce, management and entrepreneurship. [Conference: JUICE 2016]. University of Jaffna, Sri Lanka.

Stogdill, R. M. (1974). Handbook of leadership: A survey of theory and research. New York: Free Press.

Strenitzerová, M., \& Achimský, K. (2019). Employee satisfaction and loyalty as a part of sustainable human resource management in postal sector. Sustainability, 11(17), 1-30.

Sun, R., \& Henderson, A. C. (2017). Transformational leadership and organizational processes: Influencing public performance. Public Administration Review, 77(4), 554-565.

Surji, K. M. (2015). Understanding leadership and factors that influence leaders' effectiveness. European Journal of Business and Management, 7(33), 154-167. 
Tepper, B. J., \& Taylor, E. C. (2003). Relationships among supervisors' and subordinates' procedural justice perceptions and organizational citizenship behaviors. The Academy of Management Journal, 46(1), 97-105.

Veena, B. (2020). Construction related deaths and injuries alarming. New Straits Times, Malaysia.

Werner, J. M. (2000). Implications of OCB and contextual performance for human resource management. Human Resource Management Review, 10(1), 3-24.

Wright, E. S. (2017). Dialogic development in the situational leadership style. Performance Improvement, 56(9), 27-31.

Yukl, G. (2013). Leadership in organizations ( $8^{\text {th }}$ ed), Global Edition, Pearson Education Limited, Edinburgh Gate, Harlow, Essex CM 20 2JE, England.

Yukl, G., \& Fable, C. M. (1991). Importance of different power sources in downward and lateral relations. Journal of Applied Psychology, 76(3), 416-423.

Yukl, G., Gordon, A., \& Taber, T. (2002). A hierarchical taxonomy of leadership behavior: Integrating a half-century of behavior research. Journal of Leadership and Organizational Studies, 9(1), 15-32.

Zhong, L., Wayne, S. J., \& Liden, R. C. (2016). Job engagement perceived organizational support, high-performance human resource practices, and cultural value orientations: A cross-level investigation. Journal of Organizational Behavior, 37(6), 823-844. 